\title{
28 Research Square \\ Lifestyle factors and reversion to normoglycaemia by prediabetes type in PREDAPS study.
}

\section{LUCIA CEA SORIANO ( $\square$ luciaceife@gmail.com )}

Universidad Complutense de Madrid Facultad de Medicina https://orcid.org/0000-0002-7051-0730

\section{Carolina Giráldez-García}

Hospital Universitario Infanta Elena

\section{Romana Albadalejo}

Universidad Complutense de Madrid

Josep Franch-Nadal

Universitat de Barcelona Facultat de Medicina i Ciencies de la Salut

\author{
Manel Mata-Cases \\ redGDPS \\ Javier Díez-Espino \\ red GDPS
}

Sara Artola

redGDPS

Rosario Serrano

redGDPS

Enrique Regidor

Universidad Complutense de Madrid

Research article

Keywords: Prediabetes, reversion to normoglycaemia, lifestyle factors, cohort study, HbA1c, fasting plasma glucosa

Posted Date: February 7th, 2020

DOI: https://doi.org/10.21203/rs.2.22844/v1

License: (c) (i) This work is licensed under a Creative Commons Attribution 4.0 International License.

Read Full License 


\section{Abstract}

Background: Healthy lifestyle interventions and drug therapies are proven to have a positive preventative influence on normal glucose regulation in prediabetes; however, there is little evidence to support the role of these factors according to the various stage of the prediabetes state. Aims : This study aims to investigate the role of lifestyle factors on the reversion to normal glucose regulation according to the different stage of the prediabetes state based on most up-to-date American Diabetes Association (ADA) guidelines. Design and Setting: Observational prospective cohort study. The Cohort study in Primary Health Care on the Evolution of Patients with Prediabetes from 2012-2015

Methods: A total of 1184 individuals aged 30 to 74 years old were included and classified based on the ADA in three mutually exclusive groups using either fasting plasma glucose (FPG) levels (from 100-125 $\mathrm{mg} / \mathrm{dl}$, FPG group), (HbA 1c (5.7\%-6.4\%, HbA1c group) or both impaired parameters group. Information on lifestyle factors and biochemical parameters were collected at baseline Reversion to normal glucose regulation was calculated at third year of follow-up. Relationship of lifestyle factor and type of prediabetes with reversion were estimated using odds ratios (ORs) with $95 \%$ confidence intervals (Cls) adjusting by different groups of confounders.

Results: Proportion of reversion rates were 31\% for FPG group, 31\% for $\mathrm{HbA} 1 \mathrm{c}$ group and $7.9 \%$ for both altered parameters group, respectively. Optimal life style factors such as BMl<25 kg/m 2 [OR (95\% $\mathrm{Cl}): 1.90$ (1.20-3.01)], high adherence to Mediterranean diet 1.78 (1.21-2.63) and absence of abdominal obesity 1.70 (1.19-2.43) were the strongest predictors for reversion to normal glucose. ORs of reversion to normal glucose were 4.87 (3.10-7.65) for FPG group and 3.72 (2.39-5.78) for HbA1c group, taking as reference those with both impaired parameters. These estimates remained almost the same after further adjustment for biochemical parameters and lifestyle factors.

Conclusions: Although optimal lifestyle factors showed to be a positive predictor for reversion to normal glucose regulation, they do not seem to explain the differences according to the type of prediabetes.

\section{Background}

The global prevalence of diabetes among adults aged 18 and beyond, has risen from $4.7 \%$ in 1980 to $8.5 \%$ in 2014, representing almost 422 million people by 2014 [1]. Together with this trend, mortality of diabetes has scaled up to be positioned in the eight causes of dead rank worldwide [2]. Risk factors for developing diabetes type 2 have been well established and characterized [3-5], therefore interventive measures to reduce the burden of this disease has been widely spread among the different healthcare systems. In addition, several studies have concluded that adherence to a healthy lifestyle (including healthy diet, smoking cessation, increase in physical activity, reduction in alcohol consumption, and reduction in body mass index (BMI)) at age $50-75$, is associated with six to ten years increase in life years and significant improvement of quality of life as well as a reduction in prevalence of major chronic 
diseases (including cancer, cardiovascular diseases and diabetes) compare to individuals with no vast improvement in lifestyle [6-7].

Prediabetes status has been associated with a higher risk of developing diabetes type 2 . This stage is characterized by either an impaired fasting plasma glucose (IFG) or impaired glucose tolerance (IGT), or elevated glycated haemoglobin $\mathrm{A} 1 \mathrm{c}(\mathrm{HbA} 1 \mathrm{c})$ depending on the established diagnostic criteria [8]. Prior research on this topic highlight optimal lifestyle factors and drug therapies (majority oral antidiabetic medications) implementations as effective predictive positive factors to conversion to normal glucose regulation in subjects with prediabetes $[4,9-10]$. However, those interventions do not seem to play the same role depending on the type of prediabetes. For example, some studies have found a better response to glucose regulation after applying lifestyle modifications only in individuals with IGT [11]. In addition, a recent study observed how individuals with $\mathrm{HbA} 1 \mathrm{c}$ levels in range of prediabetes were less likely to revert to normal glycaemia after physical activity recommendations [12].

This apparent heterogeneous association, between optimal lifestyles and reversion to normal glycaemia regulation according prediabetes type, could be the cornerstone for individualized prevention strategies in subjects with prediabetes. However, there is little evidence on how healthy lifestyle factors can explain the variation in the proportion of patients reverting to normal glucose regulation according to type of prediabetes. In order to develop a better understanding of the following matter, this study aims to evaluate the key role of lifestyle factors on predicting reversion to normal glycaemia by type of prediabetes using a prospective cohort of individuals with prediabetes followed up by primary care physicians in Spain.

\section{Methods}

\section{Study design}

The Cohort study in Primary Health Care on the Evolution of Patients with Prediabetes (PREDAPS Study) is a prospective study encompassing two cohorts of patients: those with prediabetes status and those free of prediabetes and diabetes. Details on information and design published previously by the same authors [13]. Briefly, this prospective study conducted at the primary care setting, started in 2012. To be member of the prediabetes cohort individuals aged 30 to 74 years old were included when meeting the following prediabetes criteria based on the definition established by American Diabetes Association [14] using FPG and $\mathrm{HbA} 1 \mathrm{c}$ parameters. First group, namely i) isolated FPG group, included all individuals with $\mathrm{HbA} 1 \mathrm{c}<39 \mathrm{mmol} / \mathrm{mol}(<5.7 \%)$ and FPG $100-125 \mathrm{mg} / \mathrm{dl}$, ii) isolated elevated $\mathrm{HbA} 1 \mathrm{c}$ group, included all individuals with $\mathrm{HbA} 1 \mathrm{c} 39-47 \mathrm{mmol} / \mathrm{mol}(5.7 \%-6.4 \%)$ and $\mathrm{FPG}<100 \mathrm{mg} / \mathrm{dl}$ and iii) both altered parameters group, included all individuals with $\mathrm{HbA} 1 \mathrm{c} 39-47 \mathrm{mmol} / \mathrm{mol}(5.7 \%-6.4 \%)$ and FPG 100-125 $\mathrm{mg} / \mathrm{dl}$. Participants aged 30 to 74 years old with $\mathrm{HbA} 1 \mathrm{c}<39 \mathrm{mmol} / \mathrm{mol}(<5.7 \%)$ and FPG $<100 \mathrm{mg} / \mathrm{dl}$ were assigned to the normoglycaemia cohort. Individuals with the following criteria were excluded (to be members) from the study cohort: diabetes, terminal disease, pregnancy, surgery, or hospital admission in the previous 3 months at study entry, or any hematologic disease, which could alter $\mathrm{HbA} 1 \mathrm{c}$ values. The 
study was classified by the Spanish Drug and Health Product Agency as a Non-Interventional (Observational) Post-Authorization Study, and the protocol was approved by the Parc de Salut Mar Clinical Research Ethics Committee in Barcelona. A total of 2022 individuals gave their written informed consent for participation: 1184 subjects with prediabetes and 838 without impaired glucose metabolism.

The present study analysed the relationship between lifestyle and other variables measured at baseline and the situation of reversion to normal glycaemia in the third year of follow-up among the cohort of subjects with prediabetes. Thus, out of 1184 subjects with prediabetes, a total of $948(80.1 \%)$ attended their third follow up visit and were retained to be members of the final cohort, therefore remaining patients were excluded. Reversion to normal glucose regulation, was considered if FPG and HbA1c values were FPG $<100 \mathrm{mg} / \mathrm{dl}$ and $\mathrm{HbA} 1 \mathrm{c}<39 \mathrm{mmol} / \mathrm{mol}(<5.7 \%)$, respectively, at third year of follow up.

\section{Data Collected}

At baseline, information on biographical data, family and personal history of diabetes, smoking, alcohol consumption, diet, physical activity, drug treatment, social support and socio-economic position was obtained from each participant's clinical history and from the personal interview conducted by the physician at their practices. During the medical visit a physical examination was performed, which included anthropometry and determination of blood pressure. Similarly, blood and urine analyses were requested to determine FPG, HbA1c, lipid profile, transaminases, blood count, iron levels and renal function. Of note, all variables were treated as categorical data

Smoking habit was classified into three mutually exclusive categories: current smoker, former smoker, and non-smoker. Individuals were asked to state which of the following alternatives best reflected their alcohol consumption frequency: never drinker, former drinker, occasional drinker, or daily drinker. For the present analysis individuals were classified into non-drinkers, occasional drinkers and daily drinkers. Physical activity data were collected based on the frequency - number of times in the last two weeks- and amount -mean time in minutes for each session as well as different types of physical activity, and, on the basis of the data collected, the minutes per week of physical activity performed by each participant were estimated. Subjects were classified into two categories to their compliance with the World Health Organization (WHO) physical activity recommendations -accumulate at least 150 minutes per week of moderate aerobic activity or 75 minutes per week of vigorous aerobic activity-, or an equivalent combination of moderate and vigorous physical activity [15].

Adherence to the diet was estimated through an adaptation of the score used by Panagiotakos in the ATTICA study [16]. In each of the 20 types of food investigated, research subjects were asked about the following frequency consumption options: daily consumption, $\geq 3$ times / week, 1-2 times / week, $<1$ time / week, never or almost never. A score of 0 was assigned to a less healthy consumption and 4 to the healthiest consumption of each food categories. A score of 0 is considered minimum adherence, compared to 80 , which would be maximum adherence. Adherence to the Mediterranean diet was grouped into three categories low (0-53 points), medium (54-59 points) and high (60-80 points). 
Overweight and general obesity was defined as a Body Mass Index (BMI) $\geq 25 \mathrm{~g} / \mathrm{m}^{2}$, and abdominal obesity as a waist circumference $\geq 102 \mathrm{~cm}$ in men and $\geq 88 \mathrm{~cm}$ in women. Hypertension was defined as systolic blood pressure $\geq 140 \mathrm{mmHg}$, or diastolic blood pressure $\geq 90 \mathrm{mmHg}$, or current use of antihypertensive treatment or having a personal history of hypertension. Hypercholesterolemia was defined as total serum cholesterol $\geq 250 \mathrm{mg} / \mathrm{dl}$, high-density cholesterol level (HDL-C) of as $<40 \mathrm{mg} / \mathrm{dl}$ in men and $<50 \mathrm{mg} / \mathrm{dl}$ in women, and hypertriglyceridemia as serum level of triglycerides $\geq 200 \mathrm{mg} / \mathrm{dl}$

\section{Statistical analysis}

A descriptive analysis of the distribution of demographic characteristics, lifestyle variables, obesity, and hypertension and biochemical parameters, according to type of prediabetes was performed using the chisquare test (categorical variables). Then it was calculated the percentage of subjects who reverted to normal glycaemia according to these variables and types of prediabetes. The relationship between demographic characteristics, lifestyle variables, obesity, hypertension and biochemical parameters and the reversion to normal glycaemia was estimated by odds ratio (OR) adjusted for age and sex. Relationship between type of prediabetes and the reversion to normal glycaemia was estimated using three sequential models: adjusting for age and sex (Model A); hypertension, hypercholesterolemia, HDL levels and triglycerides (Model B), and alcohol consumption, smoking, BMl, abdominal obesity, physical activity, adherence to Mediterranean diet (Model C). Each successive model included the factors from the previous model. Finally, diagnostic criteria's of prediabetes was subdivided using as cut-off levels $\mathrm{FPG}<110$ and $\geq 110 \mathrm{mg} / \mathrm{dl}$ and $\mathrm{HbA} 1 \mathrm{c}<42$ and $\geq 42 \mathrm{mmol} / \mathrm{mol}$ ( $<6$ and $\geq 6 \%$ ), respectively, and the relationship between subtype of prediabetes and the reversion to normal glycaemia was also estimated by models A, B y C. Statistical analyses were performed using the STATA package version 12.0 (StataCorp LP, College Station, TX, USA).

\section{Results}

\section{Baseline characteristics}

Among our cohort of prediabetes, mean age was 58.7 years (median: 60 years). Amongst them, $21 \%$ of patients were classified as having isolated impaired FPG, $27.6 \%$ had isolated elevated $\mathrm{HbA} 1 \mathrm{c}$ levels and $50.9 \%$ had both altered parameters. Table 1 shows the baseline characteristics of study cohort according to type of prediabetes. There was an inverse proportion of men and women according to each prediabetes criteria, while $61 \%$ of those with isolated impaired FPG were men, corresponding percentages by isolated elevated $\mathrm{HbA} 1 \mathrm{c}$ and both parameters were $38.9 \%$ and $50.3 \%$, respectively $(p<0.001)$. Distribution of age was similar within groups, although those with isolated IFG tended to be younger. In terms of alcohol consumption, the proportion of daily drinkers were $29 \%$ among those with both altered parameters compared to $19.5 \%$ among those with isolated elevated $\mathrm{HbA} 1 \mathrm{c}$ and $34 \%$ among those with isolated impaired FPG. Those with both altered parameters had higher proportions of BMI $>25 \mathrm{~kg} / \mathrm{m}^{2}$ and abdominal obesity. There were no differences in distribution of remaining lifestyle factors as smoking, 
physical activity and adherence to diet. Those with both altered parameters had a higher frequency of hypertension and triglycerides levels and there were no differences in distribution of hypercholesterolemia or HDL levels.

\section{Reversion rates according to type of prediabetes}

At third year of follow up, there were a total of 165 (17.4\%) patients who reverted to normal glucose regulation. When stratifying by type of prediabetes, the proportion of patients reverting to normal glycaemia defined by both -HbA1c and FPG criteria had the lowest proportion of reversion $(7.9 \%)$ compared with those defined with isolated impaired FPG (31.0\%) or isolated elevated HbA1c (24.4\%), respectively (Figure 1). We subdivided the diagnostic criteria of prediabetes using as cut-off levels $\mathrm{FPG}<110$ and $>110 \mathrm{mg} / \mathrm{dl}$ and $\mathrm{HbA} 1 \mathrm{c}<42$ and $\geq 42 \mathrm{mmol} / \mathrm{mol}(<6$ and $\geq 6 \%$ ), respectively. Individuals with $\mathrm{HbA} 1 \mathrm{c}$ levels $\geq 42 \mathrm{mmol} / \mathrm{mol}(<6 \%)$ had the lowest reversion rates $(3.2 \%$ for those with FPG: $100-125$ $\mathrm{mg} / \mathrm{dl}$ and $8.7 \%$ with $\mathrm{FPG}<100 \mathrm{mg} / \mathrm{dl}$ ), while those with isolated $\mathrm{FPG}<110 \mathrm{mg} / \mathrm{dl}$ and isolated $\mathrm{HbA} 1 \mathrm{c}<42$ $\mathrm{mmol} / \mathrm{mol}(<6 \%)$ obtained the highest reversion rates (40.7\% and $32.9 \%)$ (Figure 2 ).

\section{Factors associated with the reversion to normoglycemia}

Table 2 shows the percentage of reversion according to each baseline characteristic factor as well as the OR of reversion. We did not observe any association with sex. There was a trend towards a decreased likelihood of reversion with the increase in age. Lifestyle factors such as BMI<25 kg/m² [OR 1.90 (95\% $\mathrm{Cl}: 1.20-3.01)$ ] compared to $\mathrm{BMI}>25$, absence of abdominal obesity [OR $1.70(95 \% \mathrm{Cl} 1.19-2.43)$ ] compared of having a waist circumference $\geq 102 \mathrm{~cm}$ in men and $\geq 88 \mathrm{~cm}$ in women, a high adherence to Mediterranean diet [OR 1.78 (95\% Cl 1.21-2.63)] compared to having low/median adherence and following the OMS recommendations on physical activity [OR 1.48 (95\% Cl:1.04-2.10)] compared to not following them showed to be positive predictive factors associated with reversion to normal glycaemia. Not having hypertension shown to be associated with reversion to normoglycaemia, and there was no association with biochemical parameters such as hypercholesterolemia, HDL low levels or hypertriglyceridemia

\section{Role of Lifestyle factors on reversion according to type of prediabetes}

Compared with participants with both FPG and HbA1c criteria, when adjusting by age and sex, the OR of reversion of prediabetes was 4.87 (95\% Cl: $3.10-7.65)$ among those with isolated impaired FPG and 3.72 (95\% Cl: 2.39-5.78) for those with isolated elevated $\mathrm{HbA} 1 \mathrm{c}$. When adding biochemical parameters as well as hypertension (Model B), OR remained almost constant: 4.78 (95\% Cl: $3.03-7.55)$ and 3.59 (95\% Cl: 2.30-5.60), respectively. Finally, when including lifestyle factors (Model C), OR did remain almost the same: 4.52 (95\% Cl: 2.84-7.18) for isolated impaired FPG group and 3.43 (95\% Cl: 2.17-5.42) for 
isolated elevated $\mathrm{HbA} 1 \mathrm{c}$ group (Table 3). Also, when subdividing prediabetes cohort according to levels of FPG and $\mathrm{HbA1c}$, the $\mathrm{OR}$ in de Model $\mathrm{C}$ which was similar to $\mathrm{OR}$ in the Model $\mathrm{B}$. Taking as reference those with $\mathrm{HbA} 1 \mathrm{c}$ levels $\geq 42 \mathrm{mmol} / \mathrm{mol}$ ( $\geq 6 \%$ ) and FPG $100-125 \mathrm{mg} / \mathrm{dl}$, the OR for reversion after adjusting for all factors (Model C) were as follows: isolated FPG $<110 \mathrm{mg} / \mathrm{dl}: 18.21$ (95\% Cl: 8.08-41.06), isolated FPG $\geq 110$ mg/dl: 5.75 (95\% Cl: 2.30-14.37), isolated HbA1c <42 mmol/mol (<6\%): 13.34 (95\% Cl: 6.0329.52), isolated $\mathrm{HbA} 1 \mathrm{c} \geq 42 \mathrm{mmol} / \mathrm{mol}(\geq 6 \%): 2.70$ (95\% Cl: $0.97-7.51)$, and $\mathrm{HbA} 1 \mathrm{c}<42 \mathrm{mmol} / \mathrm{mol}$ $(<6 \%)$ and FPG $100-125 \mathrm{mg} / \mathrm{dl}: 4.36$ (95\% Cl: 1.94-9.80).

\section{Discussion}

\section{Main Findings}

The current prospective cohort study included a total of 948 individuals with a prediabetes status. At the third year of follow-up, compared with the group of subjects with both altered parameters, FPG and $\mathrm{HbA1c}$, the reversion to normal glucose regulation was almost four times higher in subjects with isolated elevated $\mathrm{HbA} 1 \mathrm{c}$ and almost five times higher in subjects with isolated impaired FPG.

\section{Strengths and limitations}

This study has several strengths and limitations that deserve some comment. Several strengths and limitations should be acknowledged. To best of our knowledge, this is the first study evaluating the role of optimal lifestyle factors in the reversion to normal glucose regulation according type of prediabetes. Our study highlights the feasibility of conducting a prospective observational study, with data collected nation-wide by primary care physicians during routine clinical practice. Although the data were collected extensively and measured at fixed predetermined points (baseline data collection and regular follow-ups) the researchers were unable to determine a time-dependent variable. being unable to time-dependent variables. However, the vast majority of the factors considered in the present study are chronic conditions or long-term lifestyle factors not susceptible to a fast variation within the follow-up during the study period. Regarding to lab data, analytical determinations of FPG, $\mathrm{HbA} 1 \mathrm{c}$ and covariates were performed at different laboratories. This fact could result in some source of misclassification. Of note, since each patient was assigned to the same laboratory during the follow-up, this limitation should be minor and expected to be non-differential in relation to the outcome, as it is unlikely that the reversion could be related to the methods employed by specific laboratories. Several items included in the survey a source of misclassification might not be ruled out. To create the adherence to Mediterranean diet variable we used the food frequency questionnaire is the most commonly used instrument to assess past dietary intake in epidemiological studies. Although 24-h dietary recall and dietary records have been used to measure usual dietary intake, both instruments are expensive and unrepresentative of usual intake and therefore, inadequate for the assessment of past dietary intake (17-18). The food frequency questionnaire is the most commonly used instrument to assess past dietary intake in epidemiological studies. The (FFQ) used here, based on five food categories, is a validated instrument to asses dietary patterns (19-20) and 
it has been observed that the information it provides is a good predictor of mortality in diabetic and nondiabetic subjects (21). The instrument of measurement of physical activity here allows evaluating compliance with the recommendations of the American College of Sports Medicine (22) and the World Health Organization (23). This instrument may overestimate compliance with the recommendations because it measures the periodical activity habit such as a number of times that physical activity was performed in the last two weeks and therefore is not based on daily performances.However, it is unlikely that this overestimation is differential with respect to the type of prediabetes of the subjects. Finally, since reversion to normal glycemia might not be a permanent and chronic condition (i.e. some subjects might change from first visit to third) we decided to use as a cutoff point the third visit of follow up to ensure a minimum time-lapse to measure the reversion to normal glycemia. Therefore, the subjects who did not reach the third visit were excluded. The percentage of dropout was $21 \%$ in subjects with prediabetes defined by both $\mathrm{HbA} 1 \mathrm{c}$ and FPG criteria, $16 \%$ in subjects defined by only $\mathrm{HbA} 1 \mathrm{c}$ and $19 \%$ in subjects defined by only FGP. When evaluating the baseline characteristics of the dropped-out patients $(\mathrm{N}=236$ (19.9\%), there were no major substantial differences among both groups (Supplement table 1 ). Therefore, selection bias in our study should be minor.

\section{Comparison with existing literature}

Despite there are prior studies evaluating the proportion of reversion to normoglycaemia, all them were heterogeneous in design, duration of follow-up and criteria definition yielding a broad range of reversion rates [24-28], and only few did it according to prediabetes status criteria [12,29]. The latter, a Japanese study [29] using four prediabetes subgroups according to elevated $\mathrm{HbA} 1 \mathrm{c}$ and/or FPG, observed a greater proportion of reversion rates among those with elevated $\mathrm{HbA} 1 \mathrm{c}$ levels. In contrast, our results showed an opposite trend resulting in lower rates for individuals with $\mathrm{HbA} 1 \mathrm{c}$ levels above $42 \mathrm{mmol} / \mathrm{mol}(6.0 \%)$ regardless FPG levels, similar to the results provided by a British study [12].

A potential source of misclassification when classifying patients according to FPG levels cannot be ruled out. While FPG is subjected to not only intra-individual variability but also daily variation levels [30], $\mathrm{HbA} 1 \mathrm{c}$ reflects average plasma glucose over the previous eight to 12 weeks [31] acting as a more established parameter. In the current study, and focusing on those classified with isolated impaired FPG levels, we found how among those with FPG levels $<110 \mathrm{mg} / \mathrm{dl}$ (representing $>50 \%$ of this group) presented the highest reversion rate, and 2.3-fold times higher likelihood of reversion compared to those with FPG ranging from $110-125 \mathrm{mg} / \mathrm{dl}$, respectively. If any substantial impact of misclassification, we would not be able to see this difference.

A recent study, that applied the same prediabetes criteria than ours, observed how individuals who reverted to normal glycaemia regulation after five years of follow up, had a low insulin resistance and optimal beta-cell function at baseline [32]. Following this reasoning, is probable, that in our study population, individuals with $\mathrm{HbA} 1 \mathrm{c} \geq 42 \mathrm{mmol} / \mathrm{mol}(\geq 6 \%)$ at baseline had an increased insulin resistance 
and/or a decreased beta cell function, which might explained the lowest reversion rates found. However, we were not able to measure such physiological markers.

In the present study, baseline characteristics such as age less than 50 years, normal weight, absence of abdominal obesity, physical activity, adherence to Mediterranean diet and absence of hypertension have been associated with a higher likelihood to normal glucose regulation. There are prior studies evaluating reversion to glucose regulation using an interventional design mainly focus on optimal lifestyle actions in a prediabetes population. However, only few are focused on this relationship using a fixed period (i.e. baseline levels). The vast majority, although not all [12,33], draw similar conclusions than ours [3, 24-25, 27-28, 34]. Both, obesity and body fat distribution, are critical factors to decrease insulin sensitivity and B cells function [35]. In contrast, physical activity causes increased glucose uptake into active muscles balanced by hepatic glucose production and it improves insulin action resulting in preventing insulin resistance [36]. In addition, there is evidence that a low-glycaemic-index diet, such as Mediterranean, improves insulin sensitivity and prevents from diabetes [37]. It is therefore probable that individuals reverting to normal glucose regulation followed an optimal lifestyle behaviour long time before baseline state.

\section{Implications for research and/or practice}

There is a gap in knowledge about the extent to which healthy lifestyles explain the reversion to normal glucose regulation, according to the type of prediabetes. The current study found that adjustment for lifestyles did not modify markedly the magnitude of association between type of prediabetes and reversion, which suggests that the excess restore to normal glucose in individuals with isolated impaired FPG or isolated elevated $\mathrm{HbA1c}$ cannot be explained via these factors. Therefore, our findings suggest that beyond optimal lifestyles, FPG and HbA1c could be in themselves key markers to revert to normal glycaemia in subjects with prediabetes, especially the FPG level below $110 \mathrm{mg} / \mathrm{dl}$ and the $\mathrm{HbA} 1 \mathrm{c}$ level below $42 \mathrm{mmol} / \mathrm{mol}(6.0 \%)$.

The criteria of prediabetes are still a controversial topic, based on multiple changes in its definition. Controversy especially lies on the cut-off value levels to define FPG levels $<110 \mathrm{mg} / \mathrm{dl}$ [38-39]. Keeping in mind that almost half of the subjects with those FPG levels reverted to normal glycaemia, this might lead into an overestimation of the true prevalence of this status. Of note, those patients would not be the specific target for intensification of optimising lifestyle factors and other actions such as initiating antidiabetic therapy. In addition to existing doubts about the adequacy of FPG levels below $110 \mathrm{mg} / \mathrm{dl}$ to define prediabetes, our findings add new arguments to this controversy given the limited role of optimal lifestyles in the differences to the reversion according to the type of prediabetes. Further studies evaluating reversion to normal glucose regulation and the role of optimal lifestyle factors, together with, clinical outcomes associated to prediabetes diagnostic criteria, are warranted to not only harmonize definitions on prediabetes but also to better identify specific subjects with a low probability of normalizing glycaemia levels. 
In conclusion, optimal lifestyle factors showed to be a positive factor to reversion to normoglycaemia after three years of follow up in our prediabetes cohort however, they do not seem to explain differences in the reversion to normal glucose regulation according type of prediabetes.

\section{Declarations}

\section{Funding}

Sanofi and Novartis were both financial investors (for the development of the data collection platform, the meetings of researchers, and the monitoring of information collected at baseline).

\section{Declaration of interest}

The authors declare that they have no conflict of interest. Sanofi and Novartis had no role in the study design, analysis and interpretation of data, writing of the manuscript, nor the decision to submit the manuscript for publication.

\section{Author contribution statement}

CG-G and LC-S originated and designed the study, contributed to the analysis of the data and to the drafting of the paper. FJ-N, MM, FJS, JD-ES, SA and RS collected data of the study and contributed to the interpretation of the results and to the drafting of the paper. FJGS and RS collected data of the study and coordinated the writing of the article. RA, and ER contributed to the analysis of the data and to the drafting of the paper. All authors contributed to the final version of the article. All authors have seen and approved the final version. ER is the guarantor of the study.

The other members of the PREDAPS Study Group are: Margarita Alonso (CS De la Eria, Asturias), Beatriz Álvarez (CS Andrés Mellado, Madrid), Fernando Álvarez (CS La Calzada 2 , Asturias), J Carlos Álvarez (CS Eras de Renueva, León), Ma del Mar Álvarez (CS Hereza, Madrid), J Joaquín Antón (CS Murcia-Centro, Murcia), Oriol Armengol (EAP Poblenou, Barcelona), Luis Ávila (Consultorio Almachar, Málaga), Carmen Babace (CS Rodríguez Paterna, La Rioja), Lourdes Barutell (CS Andrés Mellado, Madrid), Ma Jesús Bedoya (CS Hereza, Madrid), Belén Benito (EAP Raval Sud, Barcelona), Beatriz Bilbeny (EAP Raval Sud, Barcelona), Marti Birules (EAP Poblenou , Barcelona), Concepción Blanco (CS Sada, A Coruña), Mª Isabel Bobé (EAP La Mina, Barcelona), Carmen Boente (CS Porriño, Pontevedra), Antonia Borras (CS Canal Salat, Baleares), Remei Bosch (EAP Girona 2 , Girona), Ma Jesús Brito (CS La Matanza, Baleares), Pilar Buil (EAP Azpilagaña, Navarra), J José Cabré (EAP Reus-1 , Tarragona), Ainoha Cambra (CS Arrabal, Zaragoza), Francisco Carbonell (CS Mislata, Valencia), Francisco Carramiñana (CS San Roque, Badajoz), Lourdes Carrillo (CS La Victoria de Acentejo, Santa Cruz de Tenerife), Ana Casorrán (CS Fuente de San Luis, Valencia), Rafael Colas (CS Santoña, Cantabria), Blanca Cordero (CS Sta. María de Benquerencia, Toledo), Xavier Cos (EAP Sant Martí de Provençals, Barcelona), Gabriel Cuatrecasas (CAP de Sarrià, Barcelona), Cristina De Castro (CS Sta. María de Benquerencia, Toledo), Manuel De la Flor (CS Ntra. Sra. de Gracia , Sevilla), Carlos De la Sen (Consultorio San Gabriel, Alicante), Rosa Mar De Miguel (EAP 
Pubillas Casas, Barcelona), A María De Santiago (Unidad Docente de Atención Familiar y Comunitaria, Guadalajara), Mercedes Del Castillo (CS Andrés Mellado, Madrid), M Ma Carmen Durán (CS Lavadores Vigo, Pontevedra), Patxi Ezkurra (CS Zumaia, Guipúzcoa), Paula Gabriel (EAP Badia del Vallès, Barcelona), Javier Gamarra (CS Medina del Campo Rural, Valladolid), Francisco García (CS Don Benito Este, Badajoz), Luis García-Giralda (CS Murcia Centro, Murcia), F Javier García-Soidán (CS Porriño, Pontevedra), Ma Teresa Gijón (CS Los Yébenes, Madrid), Albert Goday (Endocrinología Hospital del Mar, Barcelona), Ángel Gómez (CS Lasarte, Guipúzcoa), María del Carmen Gómez (CS Vélez-Málaga Norte, Málaga), J Carles González (Girona 3, Girona), María González (CS Alcantarilla Sangonera, Murcia), Esteban Granero (CS Vista Alegre Murcia , Murcia), Ángela Trinidad Gutiérrez (CS El Calero, Las Palmas), Félix Gutiérrez (CS Bombarda-Monsalud, Zaragoza), Luisa Gutiérrez (CS Beraun, Guipúzcoa), M Ángel Gutiérrez (CS Ávila Sur Oeste, Ávila), Ana Ma Hernández (CS El Calero, Las Palmas ), Mercedes Ibáñez (CS Vandel, Madrid), Rosario Iglesias (CS Lain Entralgo, Madrid), Dimas Igual (CS Manuel Encinas, Cáceres), Jaime Innenaraty (CS Hereza Leganes, Madrid), Yon Iriarte (CS Aizarnazabal-Getaria, Guipúzcua), Ángeles Jurado (CS Salvador Caballero, Granada), Rafael Llanes (Villanueva de la Cañada, Madrid), Flora López (EAP Martorell , Barcelona), Riánsares López (CS Artilleros, Madrid), Ángela Lorenzo (CS Alcalá de Guadaira, Madrid), Carmen Losada (UGC Adoratrices, Huelva), Ramón Macía (CS Roces Montevil, Asturias), Fernando Malo (CS Ares, A Coruña), José Mancera (CS Ciudad Jardín, Málaga), Ma José Mansilla (CS Martín de Vargas, Madrid), Ma Teresa Marín (CS General Ricardos, Madrid), José Luis Martín (CS Salvador Caballero, Granada), F Javier Martínez (CS Federica Monseny, Madrid), Juan Martínez (CS Yecla, Murcia), Rosario Martínez (CS Oñati, Guipúzcoa), Ma Soledad Mayayo (CS Martín de Vargas, Madrid), J Javier Mediavilla (CS Burgos Rural, Burgos), Luis Mendo (CS Cadreita, Navarra), J Manuel Millaruelo (CS Torrero La Paz, Zaragoza), Alicia Monzón (CS Vecindario, Las Palmas ), Ana Moreno (CAP San Roque, Badajoz), Pedro Muñoz (Unidad Docente de Medicina Familiar y Comunitaria, Cantabria), Xavier Mundet (EAP Carmel, Barcelona), Teresa Mur ( CAP Terrasa Sud, Barcelona), Emma Navarro (CS Añaza, Santa Cruz de Tenerife), Jorge Navarro (CS Salvador Pau, Valencia), Pedro Nogales (CS Las Águilas, Madrid), J Carlos Obaya (CS Chopera, Madrid), Francisco Javier Ortega (CS CamposLampreana, Zamora), Francisca Paniagua (CS Ciudad Jardín, Málaga), José Luis Pardo (CS Orihuela I, Alicante), Francisco Carlos Pérez (CS Martín de Vargas, Madrid), Pedro P Pérez (CS Mallen, Sevilla), Neus Piulats (EAP Raval Sud , Barcelona), Raquel Plana (CS Ponteareas, Pontevedra), Nuria Porta (CAP Terrassa Sud , Barcelona), Santiago Poveda (CS Jumilla, Murcia), Luis Prieto (CS Cáceres-La Mejostilla, Cáceres), Ramón Pujol (EAP Tremp, Lleida), Jazmín Ripoll (CS Fuente de San Luis, Valencia), Antonio Rodríguez (EAP Anglès, Girona), J José Rodríguez (CS Villaviciosa de Odón, Madrid), Ma Angeles Rollán (CS Los Yébenes, Madrid), Laura Romera (EAP Raval Nord, Barcelona), Jóse Félix Rubio (CS Lasarte, Guipúzcua), Antonio Ruiz (CS Pinto, Madrid), Irene Ruiz (EAP La Torrassa, Barcelona), Manuel Antonio Ruiz (CS Agost, Alicante), Isabel Sáenz (CS Espronceda, Madrid), Julio Sagredo (CS Los Rosales, Madrid), Alejandro Salanova (CS Fuente de San Luis, Valencia), L Gabriel Sánchez (CS Carballeda, Zamora), Manuel Sánchez (CS Vista Alegre Murcia, Murcia), Gloria Sanz (CS San José centro, Zaragoza), Mateu Seguí (UBS Es Castell, Baleares), Dulce Suárez (CS El Calero, Las Palmas ), Eduard Tarragó (EAP Bellvitge, Barcelona), Jesús Torrecilla (CS Bombarda-Monsalud, Zaragoza), José Luis Torres (CS 
Rodríguez Paterna, La Rioja), Merè Villaró (CAP Terrassa sud, Barcelona), Carmen Yuste (EAP Badia del Vallès, Barcelona).

\section{References}

1. NCD Risk Factor Collaboration (NCD-RisC).Worldwide trends in diabetes since 1980: a pooled analysis of 751 population-based studies with 4.4 million participants. Lancet 2016; 387:1513-1530.

2. Mathers CD, Loncar D. Projections of global mortality and burden of disease from 2002 to 2030. PLoS med 2006; 3:e442.

3. Perreault L, Kahn SE, Christophi CA, et al. Diabetes Prevention Program Research Group. Regression from prediabetes to normal glucose regulation in the diabetes prevention program. Diabetes Care 2009;32:1583-1588.

4. Knowler WC, Barrett-Connor E, Fowler SE, et al. Diabetes Prevention Program Research Group Reduction in the incidence of type 2 diabetes with lifestyle intervention or metformin. $\mathrm{N}$ Engl $\mathrm{J}$ Med 2002; 346:393-403.

5. Meigs JB, Muller DC, Nathan DM, et al. Baltimore Longitudinal Study of Aging. The natural history of progression from normal glucose tolerance to type 2 diabetes in the Baltimore Longitudinal Study of Aging. Diabetes 2003; 52:1475-1484. Aug;45(4):1260-1270

6. American Diabetes Association. Classification and diagnosis of diabetes: standards of medical care in diabetes-2018. Diabetes Care 2018; 41:S13-S27.

7. DREAM (Diabetes REduction Assessment with ramipril and rosiglitazone Medication) Trial Investigators, Gerstein HC, Yusuf S, Bosch J, et al. Effect of rosiglitazone on the frequency of diabetes in patients with impaired glucose tolerance or impaired fasting glucose: a randomised controlled trial. Lancet 2006; 368:1096-1105.

8. Ramachandran A, Snehalatha C, Mary S, et al. The Indian Diabetes Prevention Programme shows that lifestyle modification and metformin prevent type 2 diabetes in Asian Indian subjects with impaired glucose tolerance (IDPP-1). Diabetologia 2006; 49:289-297.

9. Engberg S, Glümer C, Witte DR, et al. Differential relationship between physical activity and progression to diabetes by glucose tolerance status: the Inter99 Study. Diabetologia 2010; 53:70-78.

10. Færch K, Witte DR, Brunner EJ, et al. Physical activity and improvement of glycemia in prediabetes by different diagnostic criteria. J Clin Endocrinol Metab 2017; 102:3712-3721.

11. Serrano R, García-Soidán FJ, Díaz-Redondo A, et al; Grupo de Estudio PREDADS Cohort Study in Primary Health Care on the Evolution of Patients with Prediabetes (PREDAPS): basis and methodology. Rev Esp Salud Publica 2013; 87:121-135.

12. American Diabetes Association. Diagnosis and classification of diabetes mellitus. Diabetes Care 2011; 34:S62-S69.

13. World Health Organization. Global recommendations on physical activity for health. World Health Organization 2010; Geneva. 
14. Panagiotakos DB, Pitsavos C, Stefanadis C. Dietary patterns: a mediterranean diet score and its relation to clinical and biological markers of cardiovascular disease risk. Nutr Metab Cardiovasc Dis 2006; 16:559-568

15. Grandjean AC. Dietary intake data collection: challenges and limitations. Nutr Rev. 2012;70(Suppl 2):S101-4

16. Willett W. Nutritional epidemiology. In: Rothman KJ, Greenlands S. Modern Epidemiology. Philadelphia: Lippincott Williams \& Wilkins, 1998: 623-642.

17. Martin-Moreno JM, Boyle P, Gorgojo L, Maisonneuve P, Fernandez-Rodriguez JC, Salvini S, Willett WC. Development and validation of a food frequency questionnaire in Spain. Int $\mathrm{J}$ Epidemiol. 1993;22:512-519.

18. Fernández-Ballart JD, Piñol JL, Zazpe I, Corella D, Carrasco P, Toledo E, Perez-Bauer M, MartínezGonzález MA, Salas-Salvadó J, Martín-Moreno JM. Relative validity of a semi-quantitative foodfrequency questionnaire in an elderly Mediterranean population of Spain. Br J Nutr. 2010;103:18081816.

19. Regidor E, Franch J, Seguí M, Serrano R, Rodríguez-Artalejo F, Artola S. Traditional risk factors alone could not explain the excess mortality in patients with diabetes: a national cohort study of older Spanish adults. Diabetes Care 2012;35:2503-9

20. Haskell WL, Lee IM, Pate RR, Powell KE, Blair SN, Franklin BA, Macera CA, Heath GW, Thompson PD, Bauman A. Physical activity and public health: updated recommendation for adults from the American College of Sports Medicine and the American Heart Association. Med Sci Sports Exerc 39; 2007: 1423-1434.

21. Word Health Organization. Global Recommendations on Physical Activity for Health. Geneve: Word Health Organization 2010.

22. Wong MS, Gu K, Heng D, et al. The Singapore impaired glucose tolerance follow-up study: does the ticking clock go backward as well as forward?. Diabetes Care 2003; 26:3024-3030.

23. Janghorbani $M$, Amini M. Normalization of glucose intolerance in first-degree relatives of patients with type 2 diabetes. Diabetes Res Clin Pract 2010; 88:295-301.

24. Tabák AG, Herder C, Rathmann W, et al. Prediabetes: a high-risk state for diabetes development. Lancet 2012; 379:2279-2290.

25. Perreault L, Pan Q, Mather KJ, et al. Diabetes Prevention Program Research Group. Effect of regression from prediabetes to normal glucose regulation on long-term reduction in diabetes risk: results from the Diabetes Prevention Program Outcomes Study. Lancet 2012; 379:2243-2251.

26. Guo VY, Yu EY, Wong CKh, et al. Validation of a nomogram for predicting regression from impaired fasting glucose to normoglycaemia to facilitate clinical decision making. Fam Pract 2016; 33:401407.

27. Heianza $Y$, Arase $Y$, Fujihara $K$, et al. Screening for pre-diabetes to predict future diabetes using various cut-off points for $\mathrm{HbA}(1 \mathrm{c})$ and impaired fasting glucose: the Toranomon Hospital Health Management Center Study 4 (TOPICS 4). Diabet Med 2012; 29:e279-e285. 
28. Mooy JM, Grootenhuis PA, de Vries H, et al. Intra-individual variation of glucose, specific insulin and proinsulin concentrations measured by two oral glucose tolerance tests in a general Caucasian population: the Hoorn Study. Diabetologia 1996; 39:298-305.

29. World Health Organization. Use of glycated haemoglobin (HbA1c) in the diagnosis of diabetes mellitus: abbreviated report of a WHO consultation. World Health Organization 2011; Geneva.

30. Kim CH, Kim HK, Kim EH, et al. Longitudinal changes in insulin resistance, beta-cell function and glucose regulation status in prediabetes. Am J Med Sci 2018; 355:54-60.

31. Kowall B, Rathmann W, Heier M, et al. Impact of weight and weight change on normalization of prediabetes and on persistence of normal glucose tolerance in an older population: the KORA S4/F4 study. Int J Obes (Lond) 2012; 36:826-833.

32. Alvarsson M, Hilding A, Ostenson CG. Factors determining normalization of glucose intolerance in middle-aged Swedish men and women: a 8-10-year follow-up. Diabet Med 2009; 26:345-353.

33. Al-Goblan AS, Al-Alfi MA, Khan MZ. Mechanism linking diabetes mellitus and obesity. Diabetes Metab Syndr Obes 2014; 7:587-591.

34. Colberg SR, Sigal RJ, Yardley JE, et al. Physical activity/exercise and diabetes: a position statement of the American Diabetes Association. Diabetes Care 2016; 39:2065-2079.

35. Kirpitch AR, Maryniuk MD. The 3 R's of glycemic index: recommendations, research, and the real world. Clinical Diabetes 2011; 29:155-159.

36. Van den Bruel A. The triumph of medicine: how overdiagnosis is turning healthy people into patients. Fam Pract 2015; 32:127-128.

37. Yudkin JS. "Prediabetes": are there problems with this label? Yes, the label creates further problems! Diabetes Care 2016; 39:1468-1471.

\section{Tables}

Table 1 Baseline characteristics of study cohort individuals according type of prediabetes. 


\begin{tabular}{|c|c|c|c|c|c|c|c|c|c|}
\hline \multirow[t]{3}{*}{ Characteristics } & \multirow{2}{*}{\multicolumn{2}{|c|}{$\begin{array}{l}\text { Isolated } \\
\text { impaired } \\
\text { FPG } \\
\text { FPG:100- } \\
125 \mathrm{mg} / \mathrm{dl} \\
\text { and } \mathrm{HbA} 1 \mathrm{c} \text { : } \\
<39 \\
\mathrm{mmol} / \mathrm{mol}\end{array}$}} & \multirow{2}{*}{\multicolumn{2}{|c|}{$\begin{array}{l}\text { Isolated } \\
\text { elevated } \\
\text { HbA1c } \\
\text { FPG: }<100 \\
\text { mg/dl and } \\
\text { HbA1c:39- } \\
47 \\
\text { mmol/mol }\end{array}$}} & \multirow{2}{*}{\multicolumn{2}{|c|}{$\begin{array}{l}\text { Both } \\
\text { altered } \\
\text { parameters } \\
\text { FPG:100- } \\
125 \text { mg/dl } \\
\text { and } \\
\text { HbA1c:39- } \\
47 \\
\text { mmol/mol }\end{array}$}} & \multirow{3}{*}{$\begin{array}{l}p \\
\text { value } \\
\text { group1 } \\
\text { vs } \\
\text { group } \\
2\end{array}$} & \multirow{3}{*}{$\begin{array}{l}p \\
\text { value } \\
\text { group1 } \\
\text { vs. } \\
\text { group } \\
3\end{array}$} & \multirow{3}{*}{$\begin{array}{l}p \\
\text { value } \\
\text { group } \\
2 \text { vs. } \\
\text { group } \\
3\end{array}$} \\
\hline & & & & & & & & & \\
\hline & $\mathrm{N}$ & $\%$ & $\mathrm{~N}$ & $\mathrm{~N}$ & $\mathrm{~N}$ & $\%$ & & & \\
\hline Sex & & & & & & & $<0.001$ & 0.010 & 0.003 \\
\hline Women & 79 & 38.9 & 240 & 240 & 240 & 49.7 & & & \\
\hline Men & 124 & 61.1 & 243 & 243 & 243 & 50.3 & & & \\
\hline Age & & & & & & & 0.181 & $<0.001$ & 0.129 \\
\hline 30-49 years & 46 & 22.7 & 60 & 60 & 60 & 12.4 & & & \\
\hline 50-64 years & 104 & 51.2 & 241 & 241 & 241 & 49.9 & & & \\
\hline $65+$ years & 53 & 26.1 & 182 & 182 & 182 & 37.7 & & & \\
\hline Smoking & & & & & & & 0.032 & 0.050 & 0.403 \\
\hline Current smoker & 28 & 13.8 & 77 & 77 & 77 & 15.9 & & & \\
\hline Former smoker & 96 & 47.3 & 180 & 180 & 180 & 37.3 & & & \\
\hline Never smoker & 79 & 38.9 & 229 & 229 & 229 & 46.8 & & & \\
\hline Alcohol consumption & & & & & & & 0.001 & 0.121 & 0.018 \\
\hline Daily drinker & 69 & 34 & 140 & 140 & 140 & 29 & & & \\
\hline Ocassionally drinker & 84 & 41.4 & 187 & 187 & 187 & 38.7 & & & \\
\hline Never drinker & 50 & 24.6 & 156 & 156 & 156 & 32.3 & & & \\
\hline BMI & & & & & & & 0.516 & $<0.001$ & $<0.001$ \\
\hline $\begin{array}{l}\text { Overweight/Obese } \\
\left(>25 \mathrm{~kg} / \mathrm{m}^{2}\right)\end{array}$ & 169 & 83.3 & 448 & 448 & 448 & 83.3 & & & \\
\hline $\begin{array}{l}\text { Normal weight (up to } \\
25 \mathrm{~kg} / \mathrm{m}^{2} \text { ) }\end{array}$ & 34 & 16.7 & 35 & 35 & 35 & 16.7 & & & \\
\hline Obesity abdominal & & & & & & & 0.536 & $<0.001$ & $<0.001$ \\
\hline Waist $\geq 88 / 102 \mathrm{~cm}$ & 119 & 58.6 & 362 & 362 & 362 & 74.9 & & & \\
\hline Waist $<88 / 102 \mathrm{~cm}$ & 84 & 41.4 & 121 & 121 & 121 & 25.1 & & & \\
\hline
\end{tabular}




\begin{tabular}{|c|c|c|c|c|c|c|c|c|c|}
\hline Physical Activity & & & & & & & 0.833 & 0.443 & 0.275 \\
\hline $\begin{array}{l}\text { Do not follow OMS } \\
\text { recommendations }\end{array}$ & 251 & 55.2 & 112 & 112 & 112 & 52.0 & & & \\
\hline $\begin{array}{l}\text { Follow OMS } \\
\text { recommendations }\end{array}$ & 91 & 44.8 & 232 & 232 & 232 & 48 & & & \\
\hline $\begin{array}{l}\text { Adherence to } \\
\text { Mediterranean diet }\end{array}$ & & & & & & & 0.006 & 0.931 & 0.031 \\
\hline Low & 51 & 25.1 & 125 & 125 & 125 & 25.9 & & & \\
\hline Medium & 98 & 48.3 & 236 & 236 & 236 & 48.9 & & & \\
\hline High & 54 & 26.6 & 122 & 122 & 122 & 25.2 & & & \\
\hline Hypertension & & & & & & & 0.161 & 0.007 & $<0.001$ \\
\hline Yes & 130 & 64.0 & 359 & 359 & 359 & 74.3 & & & \\
\hline No & 73 & 36.0 & 124 & 124 & 124 & 25.7 & & & \\
\hline Hypercholesterolemia & & & & & & & 0.061 & 0.199 & 0.379 \\
\hline Yes & 112 & 55.2 & 292 & 292 & 292 & 60.5 & & & \\
\hline No & 91 & 44.8 & 191 & 191 & 191 & 39.5 & & & \\
\hline Low HDL levels & & & & & & & 0.684 & 0.044 & 0.084 \\
\hline Yes & 38 & 18.7 & 125 & 125 & 125 & 25.9 & & & \\
\hline No & 165 & 81.3 & 358 & 358 & 358 & 74.1 & & & \\
\hline Hypertriglyceridemia & & & & & & & 0.872 & 0.008 & 0.002 \\
\hline Yes & 47 & 23.2 & 161 & 161 & 161 & 33.3 & & & \\
\hline No & 156 & 76.8 & 322 & 322 & 322 & 66.7 & & & \\
\hline
\end{tabular}

*Chi square of heterogeneity

Table 2 Percentage of reversion to normal glucose regulation and odds ratio (OR) according to the characteristics of the subjects 


\begin{tabular}{|c|c|c|}
\hline Characteristics & Percentage of reversion & $\begin{array}{l}\text { Odds ratio } \\
\text { ( } 95 \% \text { confidence interval)* }\end{array}$ \\
\hline \multicolumn{3}{|l|}{ Sex } \\
\hline Women & 16.7 & 1.00 \\
\hline Men & 18.1 & $1.06(0.75-1.49)$ \\
\hline \multicolumn{3}{|l|}{ Age } \\
\hline $30-49$ years & 31.5 & $2.92(1.82-4.69)$ \\
\hline $50-64$ years & 15.6 & $1.17(0.78-1.76)$ \\
\hline $65+$ years & 13.6 & 1.00 \\
\hline \multicolumn{3}{|l|}{ Smoking } \\
\hline Current smoker & 17.2 & 1.00 \\
\hline Former smoker & 17.8 & $1.23(0.74-2.04)$ \\
\hline Never smoker & 17.1 & $1.19(0.71-1.99)$ \\
\hline \multicolumn{3}{|l|}{ Alcohol consumption } \\
\hline Daily drinker & 14.6 & 1.00 \\
\hline Occasionally drinker & 19.9 & $1.33(0.85-2.07)$ \\
\hline Never drinker & 16.6 & $1.10(0.66-1.82)$ \\
\hline \multicolumn{3}{|l|}{ BMI } \\
\hline Overweight/Obese (>25 kg/m²) & 16.2 & 1.00 \\
\hline Normal weight (up to $25 \mathrm{~kg} / \mathrm{m}^{2}$ ) & 26.1 & 1. $90(1.20-3.01)$ \\
\hline \multicolumn{3}{|l|}{ Physical Activity } \\
\hline Do not follow OMS recommendations & 14.9 & 1.00 \\
\hline Follow OMS recommendations & 19.4 & $1.48(1.04-2.10)$ \\
\hline \multicolumn{3}{|l|}{ Adherence to Mediterranean diet } \\
\hline Low/Medium & 17.9 & 1.00 \\
\hline High & 17.2 & $1.78(1.21-2.63)$ \\
\hline \multicolumn{3}{|l|}{ Obesity abdominal } \\
\hline Waist $>=88 / 102 \mathrm{~cm}$ & 14.8 & 1.00 \\
\hline Waist $<88 / 102 \mathrm{~cm}$ & 22.9 & $1.70(1.19-2.43)$ \\
\hline
\end{tabular}




\section{Hypertension}

\begin{tabular}{lcc} 
Yes & 14.7 & 1.00 \\
\hline No & 23.1 & $1.53(1.06-2.19)$ \\
\hline Hypercholesterolemia & 17.3 & 1.00 \\
Yes & 17.5 & $1.02(0.72-1.45)$ \\
\hline No & & \\
\hline Low HDL levels & 18.5 & 1.00 \\
Yes & 17.1 & $0.98(0.65-1.47)$ \\
\hline No & & \\
\hline Hypertriglyceridemia & 14.6 & 1.00 \\
Yes & 18.5 & $1.38(0.93-2.05)$ \\
\hline No & & \\
* Sex and age adjusted odds ratio, except the odds ratios according sex and age &
\end{tabular}

Table 3 Reversion to normal glucose regulation. Odds ratio (and 95\% confidence interval) according prediabetes type and according prediabetes subtype. 


\begin{tabular}{|llll|}
\hline & Model A & Model B & Model C \\
\hline Prediabetes type & & & \\
\hline Both altered parameters & 1,00 & 1,00 & 1,00 \\
\hline Isolated elevated HbA1c & $3.72(2.39-$ & $3.59(2.30-$ & $3.43(2.17-$ \\
\hline Isolated IFG & $5.78)$ & $5.60)$ & $5.42)$ \\
& $4.87(3.10-$ & $4.78(3.03-$ & $4.52(2.84-$ \\
& $7.65)$ & $7.55)$ & $7.18)$ \\
\hline Prediabetes subtype & & & \\
\hline HbA1C $\geq 42$ mmol/mol and FPG 100- & 1,00 & & \\
125 mg/dl & & 1,00 & 1,00 \\
\hline HbA1c<42 mmol/mol and FPG 100- & $4.54(2.03-$ & $4.46(1.99-$ & $4.36(1.94-$ \\
125 mg/dl & $10.17)$ & $9.99)$ & $9.80)$ \\
\hline Isolated HbA1c $\geq 42 \mathrm{mmol} / \mathrm{mol}$ & $2.81(1.02-$ & $2.75(0.99-$ & $2.70(0.97-$ \\
\hline Isolated HbA1c $<42 \mathrm{mmol} / \mathrm{mol}$ & $7.74)$ & $7.61)$ & $7.51)$ \\
\hline Isolated FPG $\geq 110 \mathrm{mg} / \mathrm{dl}$ & $14.65(6.73-$ & $14.11(6.44-$ & $13.34(6.03-$ \\
& $31.91)$ & $30.94)$ & $29.52)$ \\
\hline Isolated FPG<110 mg/dl & $6.18(2.50-$ & $6.03(2.43-$ & $5.75(2.30-$ \\
& $15.30)$ & $14.98)$ & $14.37)$ \\
\hline
\end{tabular}

Model A: Adjusted by sex and age

Model B: Model A plus hypertension, hypercholesterolemia, HDL levels and Triglycerides

Model C: Model B plus alcohol consumption, smoking, BMI, abdominal obesity, physical activity, adherence to Mediterranean diet

All variables were considered and treated as categorical variables

\section{Figures}




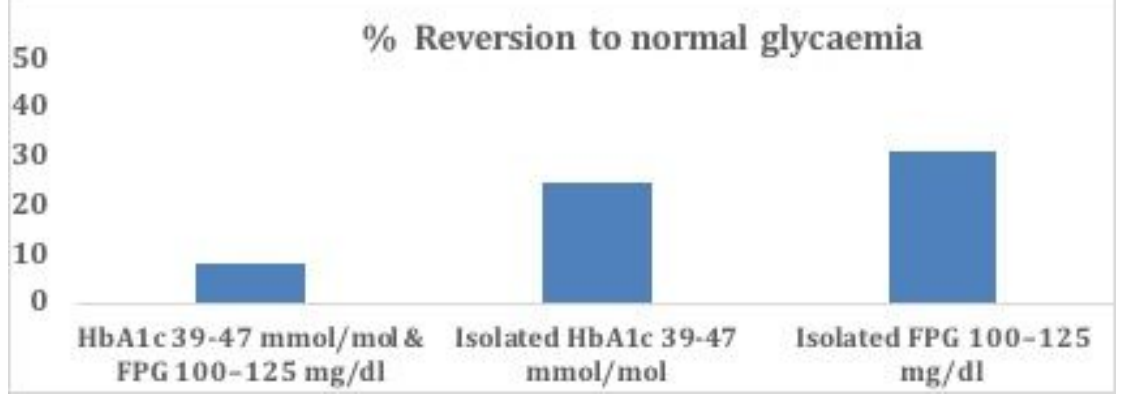

\section{Figure 1}

Proportion of patients reverting from prediabetes to normal glycaemia stratified by type of prediabetes.

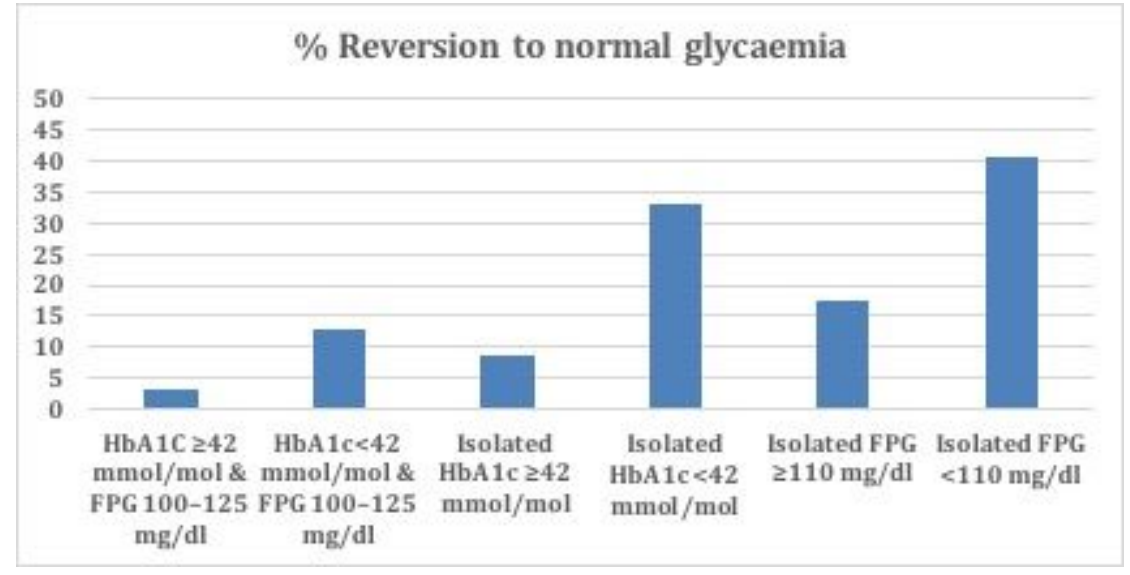

Figure 2

Proportion of patients reverting from prediabetes to normal glycaemia stratified by subtype of prediabetes

\section{Supplementary Files}

This is a list of supplementary files associated with this preprint. Click to download.

- SupplementallTable1.docx 